\title{
Modeling the transport of Saharan dust toward the Mediterranean region: an important issue for its ecological implications
}

\author{
Angelo Riccio*, Elena Chianese ${ }^{* *}$, Laura Tositti ${ }^{* * *}$, Daniela Baldacci ${ }^{* * *}$, Silvia Sandrini ${ }^{* * *}$ \\ "Deptartment of Applied Science, University of Naples "Parthenope", Centro Direzionale, Isola C4, \\ 80143-Napoli, Italy \\ e-mail: angelo.riccio@uniparthenope.it \\ "* Deptartment of Environmental Science, University of Naples "Parthenope", Centro Direzionale, Isola C4, \\ 80143-Napoli, Italy \\ ${ }^{* * *}$ Environmental Radiochemistry Laboratory, Deptartment of Chemistry, University of Bologna, \\ Via Selmi, 2, 40126-Bologna, Italy
}

\begin{abstract}
Airborne particulate matter (PM) is presently an environmental problem of primary concern, whose role in air quality, climatic and ecological issues is well recognized, though still a matter of extensive investigations (Intergovernmental Panel on Climate Change, 2007).

It is of great scientific interest to detect sources of atmospheric particulate matter and quantify their influence on the global and local scales. Unfortunately, emissions are usually not directly available, while PM concentration time series are experimentally accessible, so that the problem often consists in "inverting" these data to determine the region of influence that caused the measured concentration. In this paper we are concerned with an alternative approach to inverse modeling based on backward trajectory analysis (BTA); this approach has the potential to overcome some limitations associated with traditional BTA.

We apply this method to the analysis of PM time series from the Monte Cimone observatory, hereafter MCT, a high altitude station on the top of the Italian Northern Apennines, with the aim of estimate the contribution of Saharan dust transport on PM concentration levels registered in the Mediterranean region.
\end{abstract}

Key words: particulate matter, Saharan dust, inverse modeling, trajectory analysis.

\section{Introduction}

Every year, billions of tons of eroded mineral soils (dust) are carried from the Saharan Desert and the Sahel, via the Saharan Air Layer, to the Americas, the Caribbean, Europe and the Near East. The quantity of eroded soil lifted into the atmosphere and transported over long distances varies with global climate, tropical sea surface temperatures, regional meteorology, surface composition, and land use in the dust source region (Tegen et al. 2002; Prospero et al. 2002).

This phenomenon has deep ecological implications. Mineral dust may play an important role in affecting the climate by altering the radiation balance in the atmosphere through the radiation scattering and absorption (Tegen et al. 1997; Haywood \& Boucher 2000; Harrison et al. 2001; Sokolik et al. 2001). Mineral dust could also indirectly affect climate by affecting cloud nucleation and optical properties (Levin et al. 1996; Wurzler et al. 2000). In addition, dust can alter photochemical processes (Dickerson et al. 1997) and act as reaction surface for reactive gas species in the atmosphere (Dentener et al. 1996).

Saharan dust has been transported across the Atlantic for millions of years, depositing nutrients (primarily phosphorus) to the Amazon Basin (Swap et al. 1992), red-clay soils to the limestone islands of the Caribbean (Muhs et al. 
1990), freshwater diatoms and phytoliths to the seafloor off the coast of West Africa (Maynard 1976), and iron that periodically triggers red-tides in the Gulf of Mexico (Lenes et al. 2001; Walsh \& Steidinger 2001). African desert locusts (Schistocerca gregari) periodically make the journey from West Africa to the Windward Islands of the Lesser Antilles in Saharan dust air masses (Rosenberg \& Burt 1999).

Dust also plays an important role in paleoclimate studies. The concentration of windblown mineral dust in deepsea sediments (Rea 1994; Kohfeld \& Harrison 2001) and ice cores (Yung et al. 1996; Kohfeld \& Harrison 2001) is often used as a proxy indicator of paleoclimate aridity on the continents and of changes in the global wind systems.

For the above-mentioned considerations, it is of great scientific interest to detect sources of atmospheric particulate matter and quantify their influence on the global and local scales. In this work we investigate the long-term particulate matter (PM) experimental data from a high-altitude (2165 $\mathrm{m}$ asl) background station of the Italian Northern Apennines, Monte Cimone site ( $44^{\circ} 11^{\prime} \mathrm{N}, 10^{\circ} 42^{\prime} \mathrm{E}$ ). Data were interpreted in the light of an inverse procedure, aiming at identifying the role exerted by local and exogenous sources on the PM concentration measured at this site.

A source-receptor relationship matrix was calculated, and an inference procedure, based on the minimization of the Kullback-Leibler cross-entropy (Kullback 1959), was used to estimate a regularized solution for emission source strengths. The inverse analysis allowed the identification of major areas contributing to high concentrations at this receptor site, highlighting the role exerted by Saharan dust intrusions and local emissions on the seasonal pattern. Also, the inverse analysis allowed the indirect estimation of dust mass transported over the Mediterranean region.

\section{Materials and methods}

\subsection{Site description}

$\operatorname{MCT}\left(44^{\circ} 11^{\prime} \mathrm{N}, 10^{\circ} 42^{\prime} \mathrm{E}\right)$ is located on the highest summit of the Northern Apennines, and experiences long-range transport of air masses from Europe, the Mediterranean basin, and Africa (Bonasoni et al., 1996). The station is maintained by the Italian Meteorological Office managed by the Italian Air Force since 1945 and hosts the research platform "Ottavio Vittori" managed by the Institute of Atmospheric and Climate Sciences of the National Council of Research (ISAC-CNR). Atmospheric aerosol is collected at MCT since 1998 by a high volume PM sampler by General Metal Works collecting aerosol particles with a mean aerodynamic diameter lower than $10 \mu \mathrm{m}\left(\mathrm{PM}_{10}\right)$.

The dataset depicted in Figure 1 consists of the $\mathrm{PM}_{10}$ mass load concentrations measured at the MCT site from 1998 to 2005 and normalized at $1 \mathrm{~atm}$ and $25^{\circ} \mathrm{C}$ (standard cubic meter, hereafter SCM).

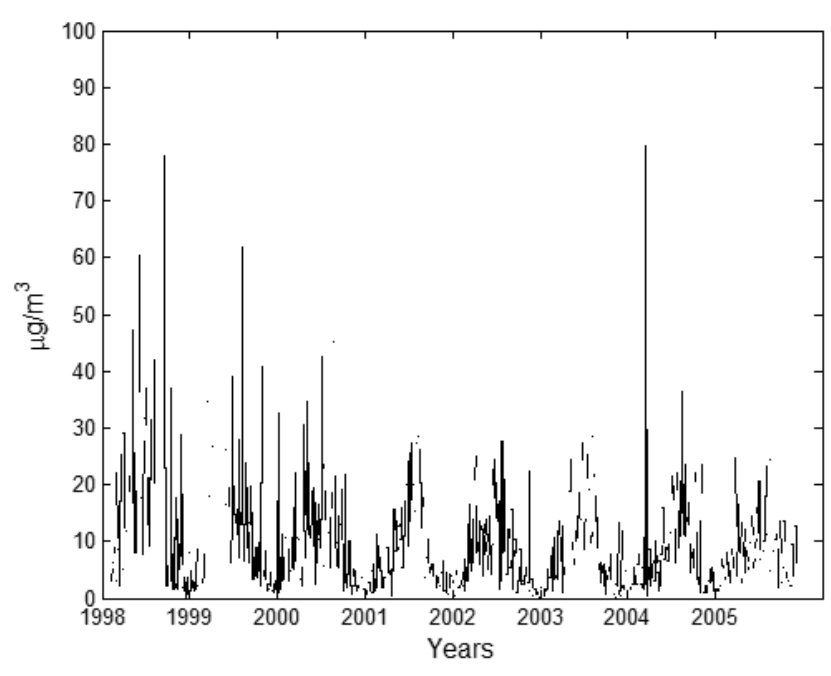

Figure 1. $\mathrm{PM}_{10}$ concentration normalized at $1 \mathrm{~atm}$ and $25^{\circ} \mathrm{C}$

Notwithstanding the two-days averaged resolution of samples, large deviations from the seasonal cycle are present, suggesting that meteorological conditions exert an important role on measured concentrations; mass load concentrations mainly fall below $10 \mathrm{mcg} / \mathrm{SCM}$ and rarely exceed $20 \mathrm{mcg} / \mathrm{SCM}$. Occasionally, concentrations attain very high values, so that the empirical probability distribution function is positively skewed, characterized by a long tail extending up to $80 \mathrm{mcg} / \mathrm{SCM}$.

The Saharan and Sahel regions are the main sources of dust into the northern hemispheric troposphere, especially during the spring and summer months, when the surface heating causes strong convective disturbances, leading to the resuspension of a huge amounts of dust from the source regions up to 600-800 hPa (Prospero 1996). The North African desert acts as an important source of mineral dust for both the western (Bonasoni et al. 2004; Escudero et al. 2005; Fisher et al. 2003), central (Barkan et al. 2005; di Sarra et al. 2001) and eastern Mediterranean area (Papayannis et al. 2005), so that it can be presumed that high concentrations are mainly due to dust outbreaks caused by large-scale advection, though contributions from relatively high polluted sites in Central and Northern Italy cannot be excluded, especially during intrusion events from the nearsurface boundary layer.

\subsection{The method: inverse modeling procedure}

In this paper we present an inverse analysis method for the identification of sources contributing to high $\mathrm{PM}_{10}$ levels at the MCT site. We combine two approaches: a Lagrangian particle dispersion model (LPDM) is used to fol- 

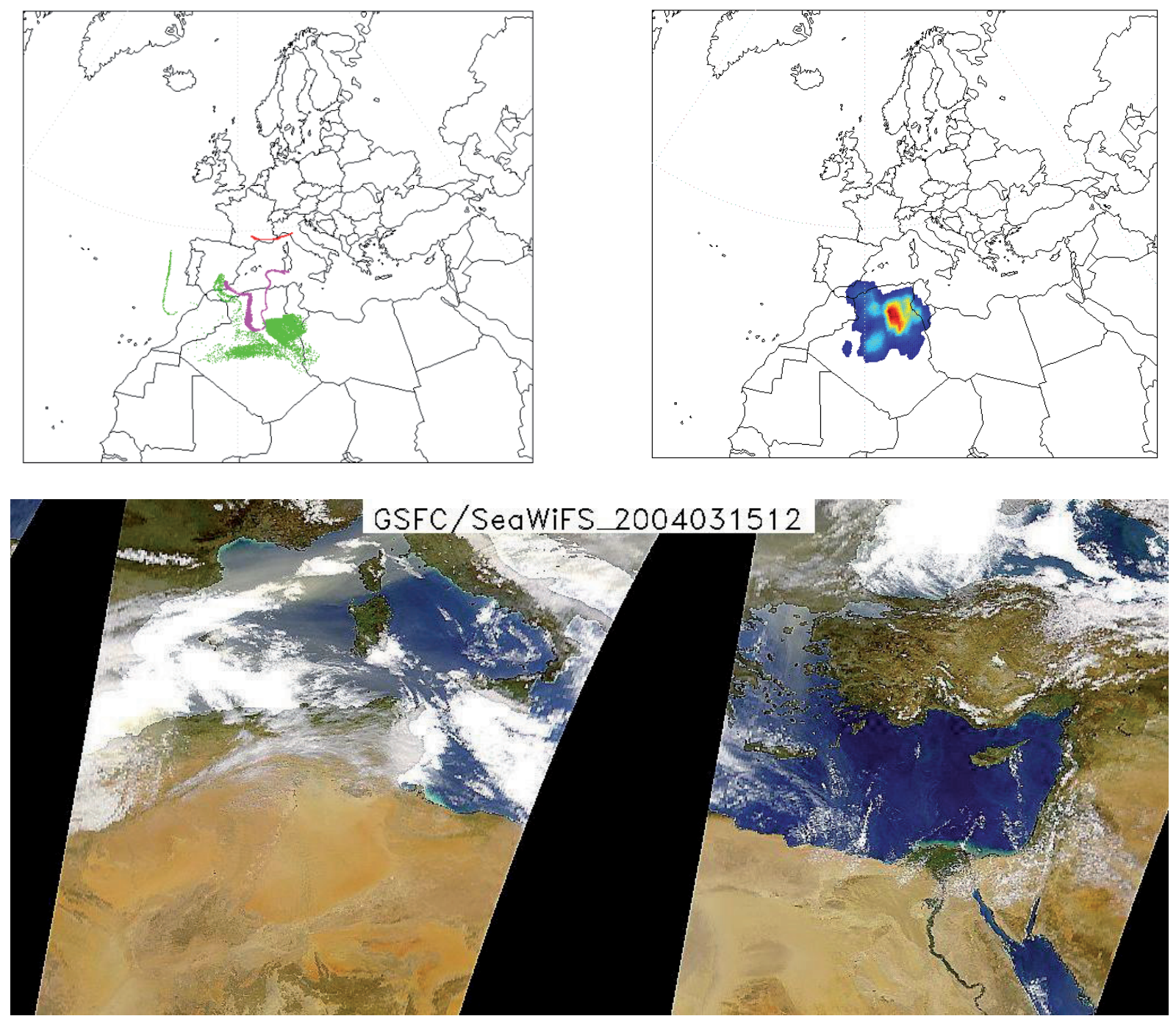

Figure 2. Top, left panel: particle positions released from the MCT measurement site. The starting release time is 00 UTC 16 March 2004. Particle trajectory are followed backward in time. Red, magenta and green colors indicate the particle positions 24 , 48 and 72 hours from the starting of release, respectively. Top-right: residence times integrated over three days from the start of release. The SeaWIFS image (bottom) of the same area showing a dust plume blowing North-Eastward over the Western Mediterranean area

low the backward trajectory of particles released from the receptor site, so that a source-receptor relationship matrix is obtained, and a negentropic approach, based on the Kullbak-Leibler cross-entropy minimization, is exploited to solve the ill-conditioned source-receptor relationship matrix.

First, the FLEXPART-WRF (Sthol et al. 2005) Lagrangian particle model was used to numerically simulate the transport and diffusion of particles. Briefly (see Seibert \& Frank 2004, for a more-in-depth derivation), this software follows the transport of hundreds thousands of tagged "particles" from the receptor backward to the hypothetical source location, following the Lagrangian trajectory associated with meteorological wind conditions.
A typical example of the output from this software is shown in Figure 2. In this example particles are continuously released during 15 March 2004. This day has been selected because it corresponds to an exceptional event occurred at MCT, with a $\mathrm{PM}_{10}$ measured concentration as high as $80 \mu \mathrm{g} / \mathrm{SCM}$ (see Fig. 1). The SeaWIFS true color image unequivocally reveals a dust plume blowing northeastward through the Western Mediterranean and reaching up to Northern/Central Italian countries. The backward analysis with the Lagrangian particles agrees with the geographical location of the plume: particles show a filamentary aspect during the first 48 hours after release, due to absence of turbulence during the transport in the free troposphere, but are dispersed over a wide area when they reach 
the Tunisia and Northeast Algeria, indicating deep convection activity. The residence times for the lowermost layer clearly show the teleconnection between the dust sources in North African countries and the measured concentration at MCT.

It can be shown (Seibert \& Frank 2004) that the residence times spent by particles within any region can be used to reconstruct the emission source strengths, given by the solution of a linear system

$$
\chi=H \sigma+\varepsilon
$$

where $\chi$ is a vector whose elements are made by concentrations measured at the receptor site, $\sigma$ are the emission source strengths from a discretized surface area, and $H$ is a matrix weighting the contribution from each discrete cell to the measured concentration; $\varepsilon$ models the measurement "errors" and uncertainties associated with this approach.

The FLEXPART-WRF system allows the estimation of matrix $H$. Unfortunately the direct solution of system (1) is not feasible, since $H$ is a ill-conditioned matrix. Due to ill-conditioning, supplementary information, i.e. a regularization technique, is needed. This means that a solution, among the many satisfying equations in (1) must be selected by a properly motivated choice. In this work we resorted to a probabilistic approach, using an informative criterion based on the minimization of the Kullback-Leibler crossentropy, also known as $I$-divergence or relative entropy (Kullback 1959).

This principle can be stated as follows: given a prior distribution, $\pi$, of all the probability distributions satisfying the given constraints, one should choose the posterior $p$ with the least cross-entropy

$$
I(p \mid \pi)=\int d(\sigma) p(\sigma) \frac{\ln (p(\sigma)}{\pi(\sigma)}
$$

provided that the above integral exists. It has been shown (Shore \& Johnson, 1980) that the Jaynes' maximum entropy principle, which in turn is an extension of Laplace's principle of insufficient reason (Jaynes 1957), is a special case of this more general principle.

The form of the prior distribution, given only the prior expected values, proceeds from a well-known property of cross-entropy minimization; precisely, if emissions are assumed to be a-priori independent, the minimum crossentropy prior distribution for emission from a given cell is the exponential function

$$
\pi(\sigma)=\frac{1}{\mu} \exp \left(-\frac{\sigma}{\mu}\right)
$$

where $\mu$ is the expected prior value for emission in that cell. Minimization of equation (2) is achieved by means of Lagrange multipliers (Bocquet 2005). The EMEP particulate matter emission data (http://webdab.emep.int), interpolated on the output grid, were used as prior expected values for European countries. Unfortunately, a-priori emission for the Saharan and African countries are not available and we used a constant a-priori emission value of $5 \mathrm{~g} /\left(\mathrm{m}^{2} \mathrm{yr}\right)$ for all desert areas.

\section{Results and discussion}

The inverse analysis procedure described in the previous section has been applied to interpret the measured concentrations at MCT. In Figure 3 the a-posteriori expected values of PM emissions for 2004 are shown.

There is a large number of cells, especially from the southern and eastern sectors which have never been implied in any episode; we do not display the a-posteriori emissions for these cells, since observations do not introduce any new information and emissions remain equal to the a-priori values. However, prior to any consideration, we want to point out not to over-interpret these results; in this work we adopted a source-receptor oriented approach, using the FLEXPART-WRF model to estimate the sensitivity of measured $\mathrm{PM}_{10}$ concentration at MCT to surface emissions. An unavoidable consequence of this approach is that sources are identified only if they are effectively 'seen' by the receptor. Seibert and Frank (2004) coined the term 'field of view', and similarly Issartel (2003) introduced the concept of 'illumination', to indicate regions in the neighborhood of the receptor which are much better seen than regions far away. For this reason, results have to be interpreted more along the lines also applied in trajectory statistics which are able to give information only on sources effectively felt by the receptor; by the same way, the numerical values should be interpreted as relative emission strengths contributing to the measured concentration at MCT, rather than their absolute estimates.

A first insight into results given by this analysis can be depicted from Figure 3. A long tongue, from the Atlantic coast of Mauritania and Western Sahara until the Libyan desert, extends along the central part of Saharan desert. A rather uniform emission strength, corresponding to about $5 \mathrm{~g} /\left(\mathrm{m}^{2} \mathrm{yr}\right)$, characterizes this area. This pattern is mainly determined by a-priori assumptions: there are a few episodes during which particles reside near the surface for cells corresponding to this tongue, so that there is no information gained by the a-posteriori analysis during the assimilation procedure (compare the a-priori with the a-posteriori emission field in Figure 3).

A more formal analysis of this aspect can also be conducted by expressing the uncertainty in the a-posterio- 

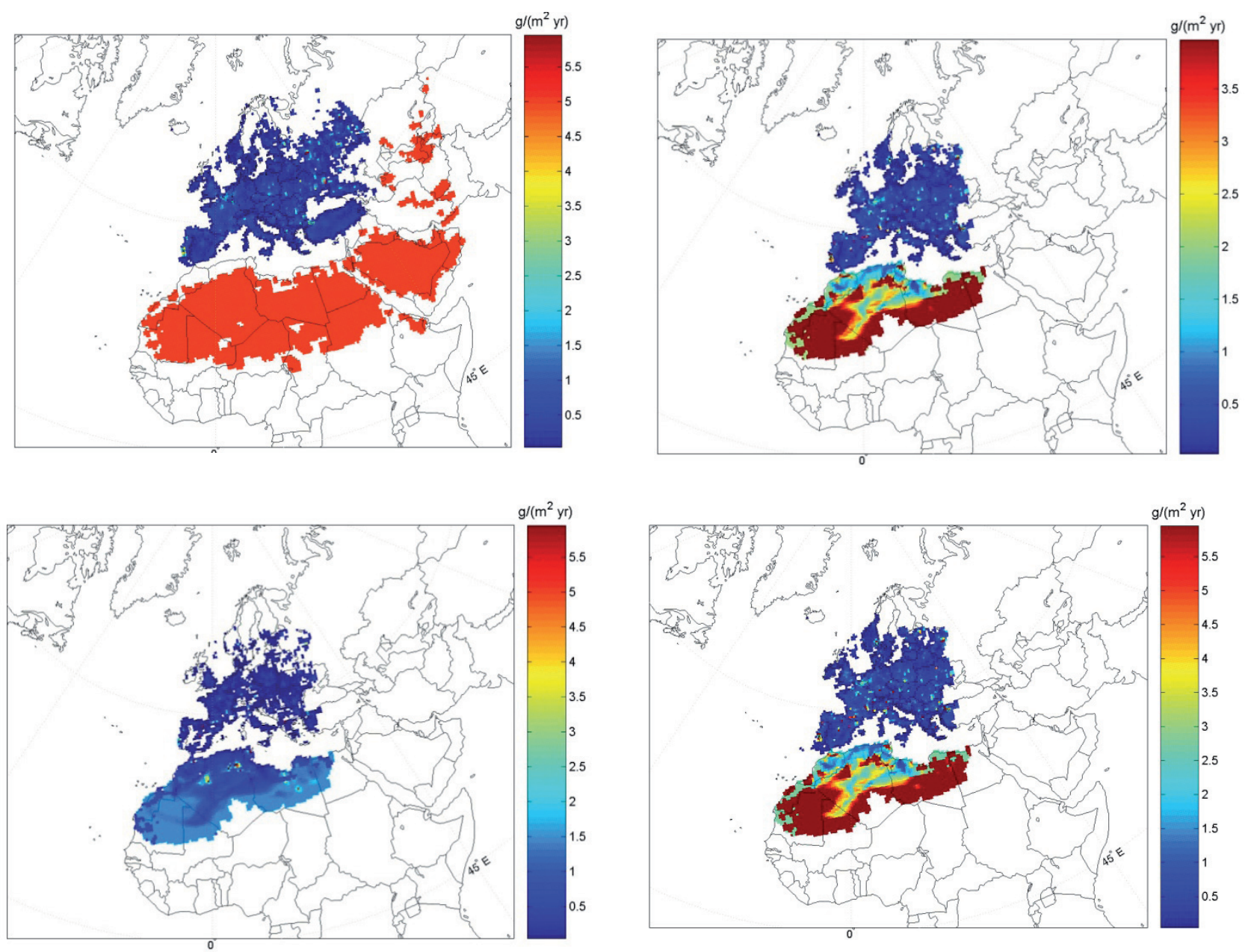

Figure 3. Apriori (top-left panel) and a-posteriori (top-right panel) emissions for 2004, estimated by the regularized inverse analysis. In the bottom panel the $25 \%$ (left) and $75 \%$ (right) percentile probability level. In these figures, emission values lower than $50 \mathrm{mg} /\left(\mathrm{m}^{2} \mathrm{yr}\right)$ have been omitted

ri analysis with probability levels; for example the $50 \%$ probability interval has as its bounds the $25 \%$ and $75 \%$ percentile probability levels, which are given by the values of $\sigma$ such that $\int_{0}^{\sigma} p\left(\sigma^{\prime}\right) d \sigma^{\prime}$ is equal to 0.25 and 0.75 for the first and third quartile, respectively. For an exponentially distributed random variable, it is easy to show that $\int_{0}^{\sigma} p\left(\sigma^{\prime}\right) d \sigma^{\prime}=1-\exp (-a \sigma)$, where $a$ is the a-posteriori estimated emission strength, so that the $k$-th probability level is given by $-\log (1-k) / a$, where $k$ denotes the percentile level, e.g. 0.25 or 0.75 . The interquartile range (Fig. 3, bottom panel) shows a large variation for this geographical area, indicating that concentrations do not introduce enough information and emissions cannot be tightly estimated.

The inverse analysis also allowed the apportionment of predicted concentrations among source countries, that is, we calculated the contribution to measured concentrations at MCT from each geographical country. Figure 4 shows some results from such an analysis. An interesting feature is the comparison between the contribution from 'Italian' and 'African' cells. A qualitative different behavior can be clearly discerned: the most important contributions from both areas occur during the spring/summer seasons, but those from African countries are more uniformly scattered, while contributions from Italy follow a seasonal cycle, with a minimum during the winter season, and a maximum during the summer season. This finding is not new; for example Barnaba and Gobbi (2004), analyzing the Aerosol Optical Thickness (AOT) data from the Moderate Resolution Imaging Spectroradiometer, found that the higher AOT values in the Po valley are observed in spring/summer. It is also worth mentioning that surface aerosol mass measurements performed all over Europe (van Dingenen et al. 2004; Putaud et al. 2004) generally show a seasonal cycle, with maxima during the cold seasons, particularly at 

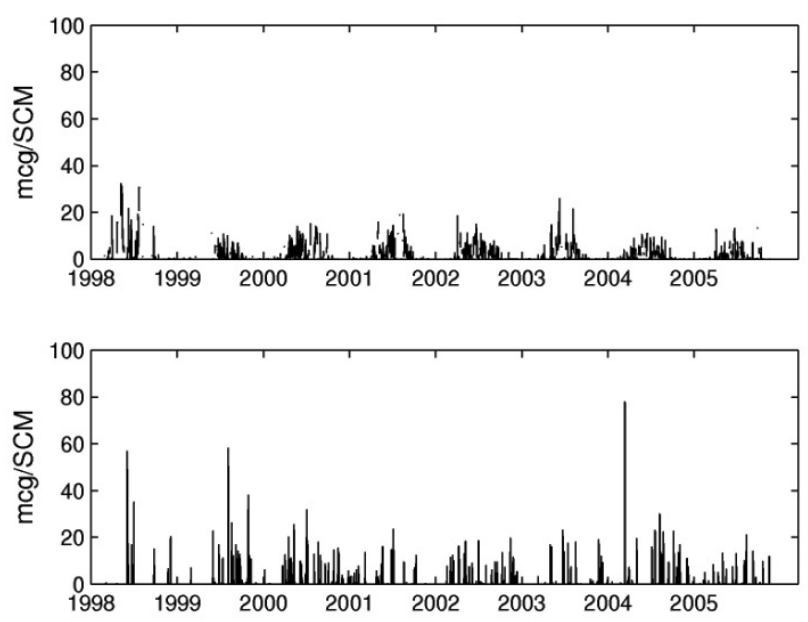

Figure 4. Top: a-posteriori $\mathrm{PM}_{10}$ concentration apportioned to emissions from Italy. Bottom: a-posteriori $\mathrm{PM}_{10}$ concentration apportioned to emissions from African countries (Algeria, Egypt, Libya, Morocco, Tunisia, Western Sahara)

polluted sites. This is explained both by the condensation of semi-volatile species at low temperatures and the lack of convective activity during the cold seasons, confining aerosol within the lower levels. The correct reproduction of the seasonal cycle is a peculiar feature of this more sophisticated modeling system and data analysis procedure: the use of a simpler trajectory model, without any boundary layer and turbulence parameterization, would had been probably unsuccessful in reproducing the seasonal cycle. Moreover, the MCT site, with its 2165 meters of altitude, is ideal for observing this occurrence. These evidences are further supported by similar studies at Jungfraujoch (Collaud Coen et al. 2004), another high altitude station in Switzerland, featuring a similar seasonal behavior, and also by the comparison of Mt. Cimone data with those of ground level station located in the Po valley as well as in Tuscany.

A rather different behavior is shown by concentrations apportioned to emissions from African countries. A seasonal cycle is still present, again with maxima during the summer season, but concentrations are more uniformly distributed. The monthly distribution of dust events are reported in Figure 5.

\section{Conclusions}

In this work we illustrate the results of an inverse analysis procedure, in order to retrieve the source emission strengths of atmospheric particulate matter. This component plays an important role for ecological, climatological and air quality issues.

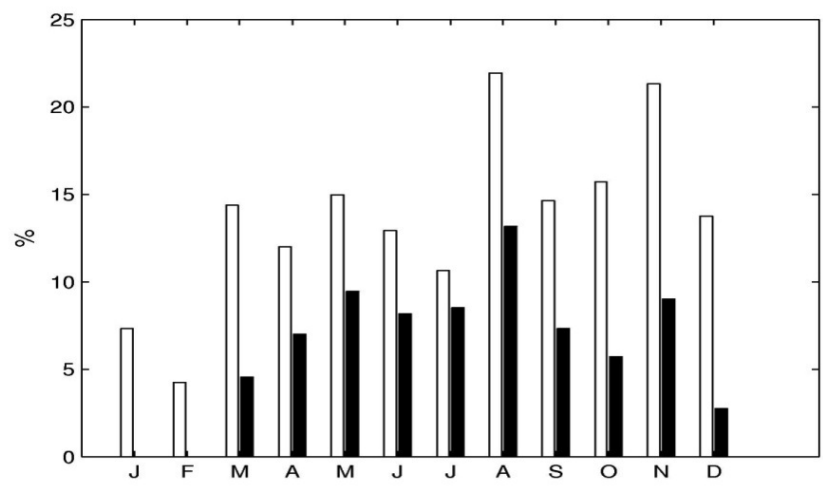

Figure 5. Monthly distribution of days (as \% of total) affected by African dust contribution. The black bars corresponds to those days for which the measured concentration at MCT exceeded $10 \mu \mathrm{g} / \mathrm{SCM}$

We analyze the results obtained by inverting a relatively long time series, whose values are measured at MCT by about ten years. We were able to identify and quantify the emission source strengths from African countries, usually associated Saharan dust outbreaks. Outbreaks are scattered all along the year, though they are concentrated in the spring/summer season. The seasonal cycle is mainly determined by the convective activity transporting the $\mathrm{PM}_{10}$ from polluted surface sites in northern, as well as Northern and Eastern European countries.

The inverse analysis procedure, combining information from an-priori emission database and observations, overcome the problems associated with this ill-conditioned problem.

\section{References}

Barkan J., Alpert P., Kutiel H. \& Kishcha P., 2005, Synoptics of dust transportation days from Africa toward Italy and central Europe, J. Geophys. Res. 110.

Barnaba F. \& Gobbi G. P., 2004, Aerosol seasonal variability over the mediterranean region and relative impact of maritime, continental and Saharan dust particles over the basin from MODIS data in the year 2001, Atmos. Chem. Phys. 4: 2367-2391.

Bocquet M., 2005, Reconstruction of an atmospheric tracer source using the principle of maximum entropy, I: Theory, Q. J. R. Meteorol. Soc. 131: 2191-2208.

Bonasoni P., Colombo T., Lenaz R., Giovanelli G., Evangelisti F., Ravegnani F., Santaguida R., Tesi, G., 1996, Effect of saharan dust transport on ozone and carbon 
dioxide concentration, [in:] S. Guerzoni, R. Chester (eds.), The impact of african dust across the Mediterranean, Environmental Science and Technology Library 11, Kluwer Academic Publishers, The Netherlands: 313-322.

Bonasoni P., Cristofanelli P., Calzolari F., Bonafé U., Evangelisti F., Stohl A., Zauli Sajani S., van Dingenen R., Colombo T. \& Balkanski Y., 2004, Aerosol-ozone correlations during dust transport episodes, Atmos. Chem. Phys. 4: 1201-1215.

Collaud Coen M., Weingartner E., Schaub D., Hueglin C., Corrigan C., Henning S., Schwikowski M. \& Baltensperger U., 2004, Saharan dust events at the Jungfraujoch: detection by wavelength dependence of the single scattering albedo and first climatology analysis, Atmos. Chem. Phys. 4: 2465-2480.

Dentener F. J., Carmichael G. R., Zhang Y., Lelieveld J. \& Crutzen P. J., 1996, Role of mineral aerosol as a reactive surface in the global troposphere, J. Geophys. Res. 101: 22869-22889.

Dickerson, R. R., Kondragunta S., Stenchikov G., Civerolo K. L., Doddridge B. G. \& Holben B. N., 1997, The impact of aerosols on solar ultraviolet radiation and photochemical smog, Science 278: 827-830.

di Sarra A., di Iorio T., Cacciani M., Fiocco G. \& Fuà D., 2001, Saharan dust profiles measured by lidar at Lampedusa, J. Geophys. Res. 106: 10335-10347.

Escudero M., Castillo S., Querol X., Avila A., Alarcon M., Viana M. M., Alastuey A., Cuevas E. \& Rodriguez S., 2005, Wet and dry dust episodes over eastern Spain, J. Geophys. Res. 110, doi: 10.1029/2004JD004731.

Fischer H., Kormann R., Klupfel T., Gurk C., Konigstedt R., Parchatka U., Muhle J., Rhee T. S., Brenninkmeijer C. A. M., Bonasoni P. \& Stohl A., 2003, Ozone production and trace gas correlations during the June 2000 MINATROC intensive measurement campaign at Mt. Cimone, Atmos. Chem. Phys. 3: 725-738.

Harrison S. P., Kohfeld K. E., Roelandt C. \& Claquin T., 2001, The role of dust in climate changes today, at the Last Glacial Maximum and in the future, Earth Sci. Rev. 54: 43-80.

Haywood J. \& Boucher O., 2000, Estimates of the direct and indirect radiative forcing due to tropospheric aerosols, Rev. Geophys. 38: 513-543.

Intergovernmental Panel on Climate Change (IPCC), 2007, Climate Change 2007: The Scientific Basis, Cambridge University Press, New York.

Issartel J. P., 2003, Rebuilding sources of linear tracers after atmospheric concentration measurements, Atmos. Chem. Phys. 3: 2111-2125.

Jaynes E. T., 1957, Information theory and statistical mechanics, Phys. Rev. 106: 620-630.

Kohfeld K. E. \& Harrison S. P., 2001, DIRTMAP: The geological record of dust, Earth Sci. Rev. 54: 81-114.
Kullback S., 1959, Information Theory and Statistics, Wiley, New York.

Lenes J. M. Darrow B. P., Cattrall C., Heil C., Vargo G. A., Callahan M., Byrne R. H., Prospero J. M., Bates D. E., Fanning K. A. \& Walsh J. J., 2001, Iron fertilization and the Trichodesmium response on the West Florida shelf, Limnol. Oceanogr. 46: 1261-1277.

Levin Z., Ganor E. \& Gladstein V., 1996, The effects of desert particles coated with sulfate on rain formation in the eastern Mediterranean, J. Appl. Meteorol. 35: 1511-1523.

Maynard N. G., 1976, Relationship between diatoms in surface sediments of the Atlantic Ocean and the biological and physical oceanography of overlying waters. Paleobiol. 2: 99-121.

Muhs D. R., Bush C. A., Stewart K. C., Rowland T. R. \& Crittenden R. C., 1990, Geochemical evidence of Saharan dust parent material for soils developed on Quaternary Limestones of Caribbean and Western Atlantic islands. Quatern. Res. 33: 157-177.

Papayannis A., Balis D., Amiridis V., Chourdakis G., Tsaknakis G., Zerefos C., Castanho A. D. A., Nickovic S., Kazadzis S. \& Grabowski J., 2005, Measurements of Saharan dust aerosols over the Eastern Mediterranean using elastic backscatter-Raman lidar, spectrophotometric and satellite observations in the frame of the EARLINET project, Atmos. Chem. Phys. 5: 2065-2079.

Prospero J. M., 1996, Saharan dust transport over the North Atlantic Ocean and the Mediterranean, [in:] S. Guerzoni \& R. Chester (eds.), The Impact of Desert Dust Across the Mediterranean, Springer, New York: 133-151.

Prospero J. M., Ginoux P., Torres O., Nicholson S. E. \& Gill T. E., 2002, Environmental characterizarion of global sources of atmospheric soil dust identifies with the NIMBUS7 total ozone mapping spectrometer (TOMS) absorbing aerosol product, Rev. Geophys., doi: 10.1029/2000RG000095.

Putaud J. P., Raes F., Van Dingenen R., Brüggemann E., Facchini M. C., Decesari S., Fuzzi S., Gehrig R., Huglin C., Laj P., Lorbeer G., Maenhaut W., Mihalopoulos N., Muller K., Querol X., Rodriguez S., Schneider J., Spindler G., ten Brink H., Tørseth K. \& Wiedensohler A., 2004, A European aerosol phenomenology2:chemical characteristics of particulate matter at kerbside, urban, rural and background sites in Europe, Atmos. Environ. 38: 2579-2595.

Rea D. K., 1994, The paleoclimatic record provided by eolian deposition in the deep sea: The geologic history of wind, Rev. Geophys. 32: 159-195.

Rosenberg J \& Burt P. J. A., 1999, Windborne displacement of desert locusts from Africa to the Caribbean and South America, Aerobiol. 15: 167-175. 
Seibert P. \& Frank A., 2004, Source-receptor matrix calculation with a Lagrangian particle dispersion model in backward mode, Atmos. Chem. Phys. 4: 51-63.

Shore J. E. \& Johnson R. W., 1980, Axiomatic derivation of the principle of maximum entropy and the principle of minimum crossentropy, IEEE Trans. Inf. Theory, IT26: $26-37$.

Sokolik I. N., Winker D. M., Bergametti G., Gillette D. A., Carmichael G., Kaufman Y., Gomes L., Schuetz L. \& Penner J. E., 2001, Introduction to special section: Outstanding problems in quantifying the radiative impacts of mineral dust, J. Geophys. Res. 106: 18015-18028.

Stohl A., Forster C., Frank A., Seibert P. \& Wotawa G., 2005, Technical note: The Lagrangian particle dispersion model FLEXPART version 6.2, Atmos. Chem. Phys. 5: 2461-2474.

Swap R., Garstang M., Greco S., Talbot R. \& Kallberg P., 1992, Saharan dust in the Amazon basin, Tellus 44: 133-149.

Tegen I., Hollrig P., Chin M., Fung I., Jacob D. \& Penner J., 1997, Contribution of different aerosol species to the global aerosol extinction optical thickness: Estimates from model results, J. Geophys. Res. 102: 23895-23916.
Tegen I., Harrison S. P., Kohfeld K. \& Prentice I. C., 2002, Impact of vegetation and preferential source areas on global dust aerosol: Results from a model study, J. of Geophys. Res., 107(D21), Doi:10.1029/2001JD000963.

van Dingenen R., Raes F., Putaud J. P., Baltensperger U., Charron A., Facchini M. C., Decesari S., Fuzzi S., Gehrig R., Hansson H. C., Harrison R. M., Hüglin C., Jones A. M., Laj P., Lorbeer G., Maenhaut W., Palmgren F., Querol X., Rodriguez S., Schneider J., ten Brink H., Tunved P., Tørseth K., Wehner B., Weingartner E., Wiedensohler A. \& Wahlin P., 2004, A European aerosol phenomenology-1: physical characteristics of particulate matter at kerbside, urban, rural and background sites in Europe, Atmos. Environ. 38: 2561-2577.

Walsh J. J. \& Steidinger K. A., 2001, Saharan dust and Florida red tides: the cyanophyte connection, J. Geophys. Res. 106: 11597-11612.

Wurzler S., Reisin T. G. \& Levin Z., 2000, Modification of mineral dust particles by cloud processing and subsequent effects on drop size distributions, J. Geophys. Res. 105: 4501-4512.

Yung Y. L., Lee T., Wang C.-H. \& Shieh Y.-T., 1996, Dust: A diagnostic of the hydrologic cycle during the Last Glacial Maximum, Science 271: 962-963. 